\title{
ECONOMETRIC ANALYSIS OF SHORT-RUN AND LONG-RUN DETERMINANTS OF AGRICULTURAL VALUE ADDITION IN AFRICA
}

\author{
1'Onoja, A. O. , ${ }^{2}$ Achike, A. I. and ${ }^{3}$ Ajibade, T. B. ${ }^{*}$ \\ 1Department of Agricultural Economics and Extension, University of Port Harcourt, Nigeria. \\ 2Department of Agricultural Economics, University of Nigeria, Nsukka \\ ${ }^{3}$ Department of Agricultural Economics and Farm Management, University of Ilorin, Nigeria

\section{ABSTRACT}

The study investigated the effects of trade openness, electricity consumption, education and technology on agricultural value addition growth in Africa. It used data accessed from World Bank Data Base (1971-2011) which were subjected to econometric tests before applying the bound test for cointegration using Autoregressive Distributed Lag model. Results indicated the existence of a steady-state long-run relationship between agricultural value addition and its hypothesized determinants. Finally, technology $(0.446)$ at $p<0.01$ and electricity consumption (1.695), at $p<0.01$ were the major long-run determinants of agricultural value addition growth. However technology (Wald stat $=-0.551$ ) with $p<0.01$, electricity (Wald Stat $=0.246$ ) at $p<0.01$ and education (Wald $F$ Stat $=-0.417$ ) with $p<0.01$ explained the variation in agricultural value addition in Africa in the short-run. It was recommended that African nations should invest on electricity generation, technology development and skill acquisitions for developing agricultural value chain on the continent

Key words: Agricultural value addition, Trade openness, Autoregressive Distributed Lag Model, Time Series Modeling, electricity consumption

\section{INTRODUCTION}

Agricultural development is critical to developing countries, especially the least developed. While agriculture declines relative to the rest of a growing economy as incomes improve, its growth is absolutely critical at early stages of development, and it can often drive export-led growth (World Bank 2014). Agriculture still remains the largest employer, the largest source of GDP, and the largest source of exports and foreign exchange earnings in most developing countries including sub-Saharan Africa countries. In Africa, approximately $65 \%$ of the 
workforce is involved in agriculture and the sector makes up 32\% of the continent's GDP (Halilu, 2014). According to Olatunji et al (2012) in a study carried out in Nigeria, there are opportunities to be developed as a nation if the governments focus on maintaining an increase in agricultural production and absorbing the inventory changes. Likewise, Oluwashola and Alimi (2007) stated that the agricultural sector provides vast potentials to solving the problems of unemployment and poverty. One of the strategies employed in the implementation of Agricultural Transformation Agenda (ATA) in Nigeria is to harness the roles of major stakeholders along the nodes of agricultural value chain (Ladele et al., 2015). The development and business communities involved in the African agriculture and agribusiness sectors have recently experienced a tremendous resurgence of interest in promoting value chains as a way to add value, diversify rural economies, and contribute to increasing rural household incomes in most sub-Saharan Africa (SSA) countries. Value chains are increasingly recognized as a means to reduce the rural poverty prevalent in the sub-Saharan Africa (World Bank 2007).

In light of this, developing agricultural value chain will go a long way in boosting export-led growth in Africa. According to United Nations Industrial Development Organization (UNIDO), Central Bank of Nigeria (CBN) and Bank of Industries, (BOI) (2010), value chain development "has almost become a magic formula for sustainable agricultural investments". World Bank (2010) observed that value chains are a key framework for understanding how inputs and services are brought together and then used to grow, transform, or manufacture a product; how the product then moves physically from the producer to the customer; and how value increases along the way. The value chain perspective contributes to pro-poor initiatives and better linking of small businesses with the market. Increasingly, the value chain approach is being used to guide and drive high-impact and sustainable initiatives focused on improving productivity, competitiveness, entrepreneurship and the growth of small and medium enterprises (SMEs) (World Bank, 2010).

The World Bank (2010) warned that despite the successes of many African exporters in selling to new markets, if they do not improve their business environments further and be competitive of their export commodities, many sub-Saharan African (SSA) countries risk being trapped into producing low-skill, low-value products and services, struggling to obtain a significant value-added share in global trade. It follows that raising the productivity and increasing the efficiency of agricultural value chains are basic to the success of SSA rural economies and to the growth of incomes of their rural populations (World Bank, 2010). 
However, some African countries are already conscious of the need to mainstream agricultural value addition into their long term economic development programmes even though these are in forms of policy statements or documents. For instance, in Nigeria, the most populous African country, it is stated in the Vision 2020 document that due to the crucial role of agriculture to Nigeria's economic development, the agricultural sector will be transformed into a profitable and sustainable sector that will be characterized by modern agricultural techniques and practices which will be greatly enhanced by technology. The desired goal is to be achieved through a renewed focus on increasing the yield/productivity of agricultural produce and export of processed agricultural products. A renewed emphasis will, therefore, be placed on substantially producing the required raw materials for agro-allied and agro-based manufacturing/processing companies (Federal Government of Nigeria, FGN, 2009). The Comprehensive Africa Agricultural Development Programme (CAADP), a programme of the New Partnership for Africa's Development (NEPAD), is directly aimed at raising productivity and increasing the efficiency of agriculture. Attaining high value addition to enhance trade performance and economic growth has been a great challenge for most countries, particularly developing countries. According to Escaith \& Tamenu (2013), most Least Developed Countries (LDCs) use imports of intermediate inputs in the production of final goods for domestic consumption. Primary product exporting countries, such as Angola, Yemen and Sudan utilize imports of intermediate products as inputs for their extractive activities. There are, however, a number of LDCs such as Bangladesh, Cambodia, Lesotho, Samoa and Haiti that use imported intermediate inputs to produce processed goods for exports, thereby linking themselves vertically in the global value chain (GVC). Yet, with a few exceptions, connecting to global production network in order to benefit from the new opportunities is a formidable challenge for most LDCs. The usual points of entry for LDCs into global value chains are agro-food, clothing and tourism sectors. Nevertheless, as highlighted by World Trade Organization, (Lamy, 2013 in Escaith \& Tamenu, 2013), in a new global world where connection to industrial networks is the key to industrialization, least developed countries are also the "least connected countries".

Despite the foregoing need for improved value chain development in agricultural product in Africa, Kalaba and Kirsten (n.d.) noted that the share of processed products has not changed considerably in agricultural exports for both the world and that of the South African Development Community (SADC). The difference is that the share of processed agricultural exports is about a quarter of agricultural exports for SADCs, while globally that share is around $45 \%$. This difference is also the reason to be concerned about the potential of SADC 
agriculture to contribute to development, job creation and poverty reduction, they reported. This potential gets unlocked, they noted, when additional processing activities take place in the producing countries, and reflected by the share of processed products in agricultural trade or total trade. According to a report prepared for the Sustainable Agriculture Group of the World Bank (2007), several SSA countries have recently improved their standing in terms of trade openness by taking advantage of new export opportunities. As a region, SSA's average trade openness in 2005, as measured by exports as a percentage of GDP, was 39 percent, an increase of 18 percent from 2002 levels. Within Africa, levels of trade openness fluctuate depending on geographic location, resource endowment, infrastructure quality, enabling environment and other pertinent issues. It was further stated that the countries showing notable increases in trade openness are non-oil producing countries (36 percent change since 2002); SSA excluding South Africa and Nigeria (33 percent change since 2002); and the countries of the Economic and Monetary Community of Central Africa (29 percent). Africa's oil-producing countries have measured a 61 percent increase in exports since 2002, but when compared to 1997-2002 levels, this is an 8 percent drop, perhaps indicating that the growth is largely due to volatility in world oil markets. Relative to other parts of Africa, trends of trade openness show poor performance by the West African Monetary Union (-6 percent) and the Common Market of Eastern and Central Africa (6 percent) (World Bank, 2007).

According to Miller and Jones (2010), agribusiness has emerged as a feasible way to channel credit to agriculture because it is less susceptible to risks than farming. Value addition has the ability to create employment, absorb excess labour from agriculture, enable rural residents to capture more margins from agriculture, hence raising rural income levels. Unfortunately, there is ample evidence to suggest that value addition in African agriculture is not sufficient to usher in the potential benefits hinted above for the continent. For instance, Ngore (2010) found that despite the existence of microfinance and promotion of value addition in Kenya, there was limited value addition and hence producers in the area received less return from agriculture. Kalaba \& Kirsten (n.d.) also noted that the problem in SADC and other African countries was that despite the evidence supporting advantages of value chain growth in agriculture, the advantages were not being taken further to processed agricultural products. Trade in the processed products was not used to advance the contribution of the sector beyond just farm activities. While some of the constraints may be structural, they observed, most of them were hypothesized to be policy-related (Kalaba\& Kirsten, n.d.). There are no studies to provide information on the real factors to be considered by policy makers when taking decisions on improving agricultural value chain in Africa. Results from such empirical studies as this 
current one will give impetus to such policies which need to be based on evidence. Besides, as more and better-funded agricultural development projects emerge in the next few years, policy professionals will require new framework and data for designing and evaluating investments in commercial agriculture. A study of this type will contribute to knowledge of value chain development and investment in Africa too. In response to Trade Policy Research Centre for Africa recent call for an evaluation of the role of trade reforms in African performance in the Global Value Chain (GVC), there is a need to critically and empirically determine the role of trade openness, a proxy for trade reforms, in Africa on agricultural value chain in the continent too. It would be recalled that TRAPCA (2014) observed that Africa is not a key player in the GVCs given the critical lack of the conditions such as logistics, skilled labour and general business environment that are enablers for firms to harness opportunities from GVCs. However, the changing nature of global trade driven by GVCs has implications for trade policy and economic development of sub-Saharan Africa. Value chains have also been used as a tool for SME development, with new methods of linking SME suppliers and service providers to the value chains of lead processors or marketers. More importantly, value chain analysis sheds light on the size of the firms participating in each link, how they are participating or could be participating in the chain, and opportunities to facilitate or improve those linkages. This is particularly crucial in agriculture, where governments and aid agencies are confronted with the challenge of including small farmers in modern value chains so that they can benefit from the globalization of markets. The value chain concept is therefore not only relevant to deal with growth, but also with the equity dimension of the modernization of the agri-food systems (World Bank, 2010). This study is therefore designed to ascertain the major determinants of long and short run determinants of value addition in African agriculture. Specifically the study's objective is to evaluate the effects of trade openness, electricity consumption, education and technology on agricultural value addition growth in Africa from 1971-2011.

\section{MATERIALS AND METHODS}

The study focuses on the African continent's economy. Maps of World (2013) indicated that Africa's latitude and longitude lie between $9.1021^{\circ} \mathrm{N}, 18.2812^{\circ} \mathrm{E}$. Africa covers a total land area of about 30.2 million square kilometers (11.7 million square miles) which is more than one-fifth of the world's land area. Africa's population stood at 0.8 billion. Her population growth rate was estimated at $2.5 \%$ and $2008 \mathrm{GNI}$ per capita was estimated at $\$ 1,082$ (World Bank, 2013). According to the World Bank (2014), Agriculture provides source of livelihood for 
about 75 percent of the population. The World Bank (2014) reported that the global financial crisis halted a half decade of high economic growth in many African countries significantly pulling down the average growth rates from 6.2 percent in 2007 to a projected 1.7 percent in 2009. Remittances and the private capital flows were also diminished, slowing down progress toward the Millennium Development Goals.

\section{Data Collection and Analytical Technique}

Secondary data which include economic development indicators spanning 40 years (19712011), obtained from the World Bank data base was used for empirical analysis in this study. Data used in this study include: the value added in agricultural sector, agricultural machinery/tractors, electric power consumption, secondary school enrolments and trade openness (exports+imports/GDP) in US dollars.

In order to examine the short and long run determinants of Agricultural Value Addition in Africa, the Bound Testing approach was employed. Secondary data used in this study were subjected to preliminary econometric tests for heteroscedasticity, serial correlation, normality and stability before applying the Bound Test for cointegration using Autoregressive Distributed Lag (ARDL) model.

The Bounds testing technique's use is predicated on three validations. Firstly, Pesaran et al. (2001) advocated the use of the ARDL model for the estimation of level relationships because the model suggests that if the order of the ARDL has been identified, the relationship may be estimated by OLS method. Secondly, the bounds test for cointegration permits a mixture of $\mathrm{I}(1)$ and I(0) variables as regressors. In other words, the order of integration of appropriate variables may not necessarily be the same hence the ARDL technique has the advantage of not requiring a specific identification of the order of the underlying data. Thirdly, the technique is fit for small or finite sample sizes (Pesaran et al., 2001).

In line with Pesaran et al. (2001) and Atif et al. (2010), the vector autoregression (VAR) of order $p$, denoted VAR $(p)$, for the following Agricultural Value addition function were thus assembled as:

$Z_{t}=\mu+\sum_{i=1}^{p} \beta_{i} z_{t-i}+\varepsilon_{t}$ 
where $z_{t}$ is the vector of both the dependent and the set of explanatory variables modelled in the study. Subsequently, a vector error correction model (VECM) was developed as follows:

$$
\Delta z_{t}=\mu+\alpha t+\lambda z_{t-1}+\sum_{i=1}^{p-i} \gamma_{t} \Delta y_{t-i}+\sum_{i=1}^{p-1} \gamma_{t} \Delta x_{t-i}+\varepsilon_{t}
$$

Where $z_{t}$ is the vector of both $x_{t}$ and $y_{t}$, where $y_{t}$ is the dependent variable defined as the level of agricultural value addition in Africa over the period in review (agval), $x_{t}$ is the vector matrix which represents a set of explanatory variables and this includes: technology proxied by number of machineries and tractors (tech), education proxied by secondary school enrolment number (edu); infrastructure proxied by electricity consumption in African economy over the period in kilowatts (elect), and $t$ is a time or trend variable.

Where $\Delta$ is the first-difference operator and long-run multiplier matrix $\lambda$, which is stated as:

$$
\lambda=\left[\begin{array}{l}
\lambda_{Y Y} \lambda_{Y X} \\
\lambda_{X Y} \lambda_{X X}
\end{array}\right]
$$

The diagonal elements of the matrix are unrestricted, so the selected series can be either $\mathrm{I}(0)$ or I(1). If $\lambda_{Y Y}=0$, then $Y$ is I(1). In contrast, if $\lambda_{Y Y}<0$, then $Y$ is I( 0$)$. According to Pesaran et al. (2001), $y_{t}$ must be I(1) variable, but the regressor $x_{t}$ can be either I(0) or I(1). In this study, y, agval series was I(1) as indicated in Table 1.

According to Atif et al (2010), the VECM procedures described above are imperative in the testing of at most one cointegrating vector between dependent variable $y_{t}$ and a set of regressors, $x_{t}$. To derive the empirical model, the postulations made by Pesaran et al. (2001) in Case III, that is, unrestricted intercepts and no trends was followed. After imposing the restrictions $\lambda_{Y Y}=0, \mu \neq 0$ and $\alpha=0$, the hypothesized function can be stated as the following unrestricted error correction model (UECM):

$$
\begin{aligned}
& d(\text { Inagval })=\beta_{0}+\beta_{1} \operatorname{lnagval}(-1)+\beta_{2} \operatorname{Intech}(-1)+\beta_{3} \operatorname{Inelect}(-1)+\beta_{4} \operatorname{Inedu}(-1)+\beta_{5} \operatorname{Intop}(-1)+ \\
& \beta_{6} d(\text { Inagval }(-1))+\beta_{7} d(\operatorname{Intech}(-1))+\beta_{8} d(\operatorname{Inelect}(-1))+\beta_{9} d(\operatorname{Inedu}(-1))+\beta_{10} d(\operatorname{Intop}(-1))+\mu
\end{aligned}
$$


Where, $d$ = differenced operator; agval = value added in agricultural sector (\% of GDP); tech = Agricultural machinery, tractors (proxy for technology); elect = Electric power consumption (kWh per capita); edu (i.e. level of education) = total number of secondary school enrolments; and top=trade openness (exports+imports/GDP in US dollars); $\mu=$ noise disturbance term; $b_{1}$ $-b_{10}=$ slope coefficients estimates of respective explanatory variables.

Equation (4) also can be viewed as an ARDL of order ( $p, q, r)$ and it indicates that agval (agricultural value addition) tend to be influenced and explained by its past values.

The structural lags are established by using minimum Akaike's information criteria (AIC). From the estimation of UECMs, the long-run elasticities are the coefficient of one lagged explanatory variable (multiplied by a negative sign) divided by the coefficient of one lagged dependent variable (Bardsen, 1989 as cited in Atif et el, 2010). For example, in equation (4), the long-run inequality, technology (tech) and electricity (elect) elasticities are $\left(\beta_{2} / \beta_{1}\right)$ and $\left(\beta_{3} /\right.$ $\beta_{1}$ ) respectively. The short-run effects are captured by the coefficients of the first-differenced variables in equation (4).

After regression of Equation (4), the Wald test (F-statistic) was computed to differentiate the long-run relationship between the concerned variables. The Wald test was carried out by imposing restrictions on the estimated long-run coefficients of agricultural value addition levels (agval), technology proxy (tech), level of education of the citizens (edu) and the proxy for infrastructure, i.e. electricity consumption (elect). The null and alternative hypotheses are as follows:

$H_{0}=\beta_{1}=\beta_{2}=\beta_{3}=\beta_{4}=\beta_{5}=0$ (no long-run relationship)

Against the alternative hypothesis,

$H_{0} \neq \beta_{1} \neq \beta_{2} \neq \beta_{3} \neq \beta_{4} \neq \beta_{5} \neq 0$ (a long-run relationship exists)

The computed F-statistic value were then evaluated using the critical values tabulated in Table Cl (iii) of Pesaran et al. (2001). Pesaran et al (2001) held that the lower bound critical values assumed that the explanatory variables $x_{t}$ were integrated of order zero, or $\mathrm{I}(0)$, while the upper bound critical values assumed that $x_{t}$ are integrated of order one, or I(1). Therefore, if the computed F-statistic is smaller than the lower bound value, then the null hypothesis is accepted and it would be concluded that no long-run relationship exists between agricultural value addition (agval) and its determinants. Conversely, if the computed F-statistic is greater than the upper bound value, agricultural value addition (agval) and its 
determinants share a long-run level relationship. On the other hand, if the computed $F$ statistic lies between the lower and upper bound values, then the results are inconclusive.

\section{RESULTS AND DISCUSSION}

Phillips Perron (PP) unit root test was a preliminary test applied in checking the order of integration of the series (Table 1.0). In Table 3 the results of the bounds co-integration test demonstrate that the null hypothesis of no co-integration against its alternative of presence of co-integration is hereby rejected at the $10 \%$ significance level. The computed F-statistic of 3.79 is greater than the upper critical bound value of 3.52 , thus indicating the existence of a steady-state long-run relationship between agricultural value addition, agribusiness technology (farm machineries/tractors) and infrastructure especially electricity consumption in Africa

Table 1.0 Results of Unit Root Tests on the series using Philips Perron Approach

\begin{tabular}{llll}
\hline Variable or Series & $\begin{array}{l}\text { Philips Perron } \\
\text { Statistics At Levels }\end{array}$ & $\begin{array}{l}\text { Philips Perron } \\
\text { 1st Difference } \\
\text { Statistics }\end{array}$ & REMARK \\
\hline AGVAL & $-1.988074(\mathrm{NS})$ & $-6.895404^{* * *}$ & $\mathrm{I}(1)$ \\
TOP & $-4.535488^{* * *}$ & $\mathrm{NA}$ & $\mathrm{I}(0)$ \\
TECH & $-1.744471(\mathrm{NS})$ & $-6.275443^{* * *}$ & $\mathrm{I}(1)$ \\
ELECT & $-1.547591(\mathrm{NS})$ & $-4.951103^{* * *}$ & $\mathrm{I}(1)$ \\
EDU & $-1.936965(\mathrm{NS})$ & $-5.808278^{* * *}$ & $\mathrm{I}(1)$ \\
\hline
\end{tabular}

NB: The null hypothesis is that the series is non-stationary [I(1)], or contains a unit root. The rejection of the null hypothesis is based on MacKinnon (1996) critical values. The lag length are selected based on SIC criteria, this ranges from lag zero to lag two. *, ** and *** indicate the rejection of the null hypothesis of non-stationary at 1\%, 5\% and $10 \%$ significant level, respectively. 
Table 2: Estimated Model Based on Equation (4)

\begin{tabular}{lllll}
\hline Variables & Coeff. & $\begin{array}{l}\text { Std. } \\
\text { Error }\end{array}$ & t-Stat. & Prob. \\
\hline Constant & 0.139 & 1.365 & 0.102 & 0.920 \\
Inagval(-1) & -0.551 & 0.161 & $-3.427^{* * *}$ & 0.002 \\
Intech(-1) & 0.246 & 0.083 & $2.979^{* * *}$ & 0.006 \\
Inelect(-1) & -0.417 & 0.136 & $-3.067^{* * *}$ & 0.005 \\
Inedu(-1) & 0.054 & 0.039 & 1.390 & 0.175 \\
Intop(-1) & 0.107 & 0.120 & 0.886 & 0.383 \\
d(Inagval(-1)) & 0.021 & 0.164 & 0.130 & 0.897 \\
d(Intech(-1)) & -0.144 & 0.109 & -1.320 & 0.198 \\
d(Inelect(-1)) & -0.313 & 0.353 & -0.888 & 0.382 \\
d(Inedu(-1)) & -0.096 & 0.042 & $-2.283^{* *}$ & 0.030 \\
d(Intop(-1)) & 0.041 & 0.143 & 0.288 & 0.776 \\
R-squared & 0.500 & & & \\
Adjusted R-squared & 0.321 & & & \\
F-statistic & 3.795 & & & \\
Prob(F-statistic) & 0.016 & & & \\
Akaike info criterion & -3.528 & & & \\
Schwarz criterion & -3.059 & & & \\
\hline
\end{tabular}

NB: ${ }^{* *},{ }^{* * *}$ denote significant at $5 \%$ and $1 \%$ statistical significant levels

Table 3: Bounds Test for Cointegration Analysis

\begin{tabular}{lll}
\hline Critical value & Lower Bound Value & Upper Bound Value \\
\hline $1 \%$ & 3.74 & 5.06 \\
$5 \%$ & 2.86 & 4.01 \\
$10 \%$ & 2.45 & 3.52 \\
\hline
\end{tabular}

Note: Computed F-statistic: 3.79(Significant at 0.10 marginal values with 3.52 as upper bound value).Critical Values are cited from Pesaran et al. (2001), Table Cl (iii), Case 111: Unrestricted intercept and no trend. 


\section{Diagnostics:}

Before applying the model estimates for economic analysis, the results were subjected to several econometric tests. These include tests for heteroscedasticity, serial correlation, normality and stability (Greene, 2008; Gujarati \& Sangeetha, 2007). The econometric tools employed included Breusch-Pagan-Godfrey, Breusch-Godfrey Serial Correlation LM Test, Jarque-Bera, Specification tests (Ramsey RESET test) and CUSUM tests respectively. The estimated diagnostic indicators are summarized as follows:

Jarque Bera test (see Figure 1$)=0.823 N S$ ( $p=0.662$; i.e. $p>0.10$ ); Breusch-Godfrey Serial Correlation LM Test $=0.413 \mathrm{NS}(p=0.666$, i.e. $p>0.10)$; Heteroskedasticity Test using Breusch-Pagan-Godfrey F statistic $=0.940 N S$ ( $p=0.513$; i.e. $p>0.10$ ); Average VIF $=8.196$ (No severe threat of multicollinearity); specification test using Ramsey RESET test estimated t statistic $=0.452 \mathrm{NS}(p=0.655$, i.e. $p>0.10)$. NB: "NS" implies the statistic is not significant at the relevant statistical level.

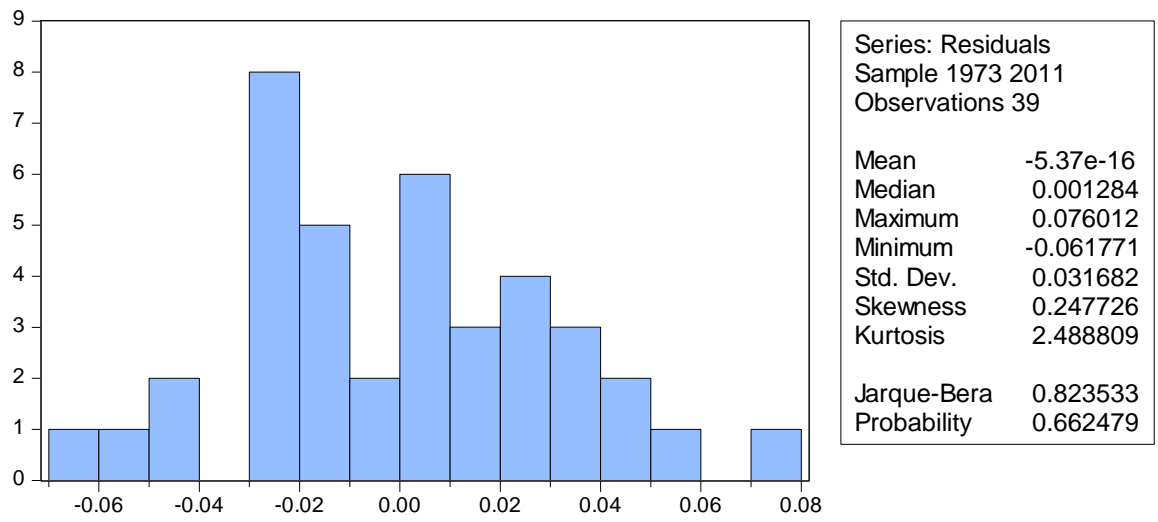

Figure 1. Results of test for skewness of the residuals (Jarque-Bera test)

The foregoing results imply that the model's residuals were normally distributed, devoid of significant presence of serial correlation, free from presence of heteroskedasticity threats, not fraught with severe threat of multicollinearity and properly specified or not mis-specified. These properties are desirable properties of OLS models. Since our model exhibit all the desirable properties of OLS, we conclude that our model is very reliable for economic analysis and forecasting. The stability of the model is evidenced from the results of the stability test using CUSUM test as indicated in the diagram in figure 2 . Since the residual plot 
did not fall outside the $5 \%$ significant boundaries, the estimates are deemed stable over the period.

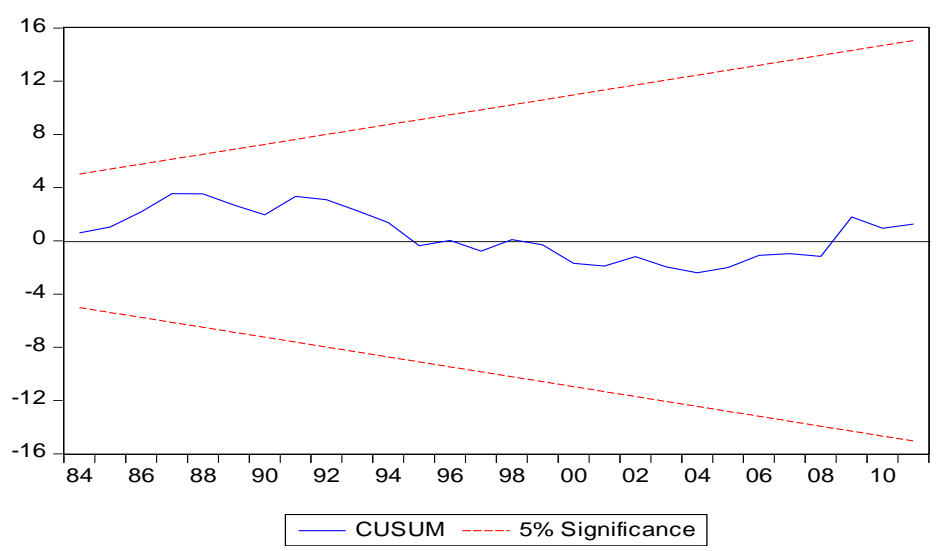

Figure 2.Diagram indicating the residuals' performance or pattern with respect to its stability. If the curved line which represents the residuals were to fall outside the two extreme lines representing the critical regions, the residuals would have been regarded as unstable.

Applying equation (5), the results depicted on Table 4 indicate that two variables, infrastructure in form of electricity (Inelect), and level of technology accessible to agribusiness firms (Intech) in form of farm machineries/tractors exerted significant long-run influences on agricultural value addition levels in Africa respectively over the period in review. The lagged value of agricultural value addition in the immediate past year (1st lag) equally exerted significant positive effect on the level of agricultural value addition in Africa too. The slope (coefficient) of technology (0.446) was positive and significant at $p<0.01$. If there is one percent increase in number of farm machineries/tractors, agricultural value addition levels increased 44.6 percent. The finding agreed with Reid (2011) who found that mechanization is one factor that has had a significant effect on modern agriculture. Mechanized harvesting, for example, was a key factor in increasing cotton production in the last century, he noted. Electricity consumption or access also exerted a positive effect on agricultural value addition in the continent with a slope coefficient of $1.695(p<0.01)$, implying that a percentage increase in the supply of electricity would result in an increase of agricultural value addition by 169.5 percent. The latter result underscores the relevance of electricity supply in Africa. It becomes very evident here that Africa would have been losing a lot of revenue in loss of value addition in her agricultural production. It is also clear from these findings that farm machineries including tractors and all necessary processing machines for transforming 
agricultural products from their raw forms are significant inputs as well as sources of investment in African agriculture.

Table 3: Bounds Test for Cointegration Analysis

\begin{tabular}{lll}
\hline Critical value & Lower Bound Value & Upper Bound Value \\
\hline $1 \%$ & 3.74 & 5.06 \\
$5 \%$ & 2.86 & 4.01 \\
$10 \%$ & 2.45 & 3.52 \\
\hline
\end{tabular}

Note: Computed F-statistic: 4.304(Significant at 0.01 marginal values with 4.01 as upper bound value).Critical Values are cited from Pesaran et al. (2001), Table Cl (iii), Case 111: Unrestricted intercept and no trend.

Table 4: Long-Run Elasticities of Agricultural Value Additions in Africa Based on Equation 4

Dependent Variable: $\mathrm{d}($ Inagval)

\begin{tabular}{llll}
\hline Variables & $\begin{array}{l}\text { Normalized } \\
\text { Coefficients }\end{array}$ & P Values & Remarks \\
\hline Inagval(-1) & 1 & 0.002 & Significant at 1\% \\
Intech(-1) & 0.446 & 0.006 & Significant at 1\% \\
Inelect(-1) & 1.695 & 0.005 & Significant at 1\% \\
Inedu(-1) & 0.129 & 0.175 & Not Significant \\
Intop(-1) & -1.981 & 0.383 & Not Significant \\
\hline
\end{tabular}

Results of short-run causality tests using Wald test are presented in Table 5 . The null hypothesis summary results gave an estimated F-statistic of $3.600(p<0.01)$ affirming the need to reject the overall null hypothesis of no causality in the restricted explanatory variables on the agricultural value addition in the continent on the short run. Specific restricted coefficients estimated returned marginal $p$ values for three factors which were all significant at $p<0.01$. These variables included Intech, i.e. technology, with Wald $F$ coefficient estimate of -0.551 ; electricity consumption (Inelect) whose Wald $F$ statistic was 0.246 and thirdly, education level (Inedu) with an estimated Wald F-statistic of -0.417 . The results imply that the levels of farm technology, infrastructure (especially electricity supply) and educational attainment in African economies were the most significant short-run determinants of 
agricultural value addition. The negative significant effect of technology on agricultural value addition on the short run here could imply that appropriate technology were not being used in value addition process in Africa. However, that the variable is still significant corroborated Reid (2011)'s findings that technology was a very important factor in agricultural value addition. The significant and positive contribution of electricity to agricultural value addition in this study is in agreement with the theory of the Competitive Diamond Model as well as the findings of Venkatachalam (2003) and UNIDO (2006).

Table 5: Short-run Causality Test (Wald Test F-statistic) of Agricultural Value Addition in Africa: Based on Equation (4)

Dependent Variable:d(Inagval, agricultural value addition)

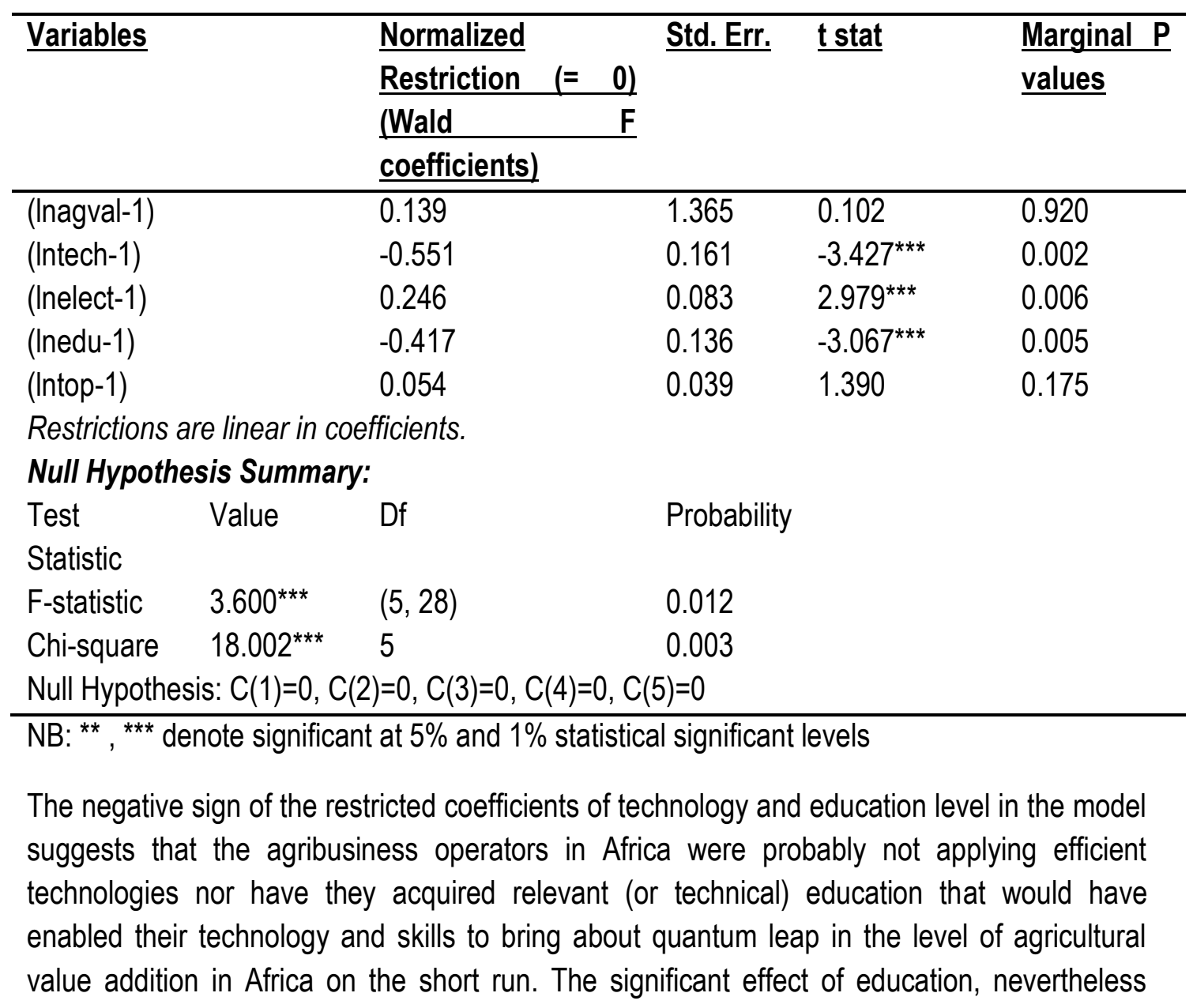


underlies the earlier position of Bharati and Chaudhury (2012) and the Competitiveness Diamond models' view that education was a significant factor in determining the level of competitiveness of a firm's (or in this case, an industry's). The negative sign could be interpreted as qualifying the quality of labour in Africa which can be generally adjudged as not being very skilled, hence bringing about negative consequences on the value addition level in African agricultural industry. It is not surprising that trade openness was not a significant determinant of value addition in African agriculture even though it could be a determinant in other places. In De Vylder (2007)'s report, it was observed that sub-Saharan Africa could not feed herself but depended too much on food imports. Over one third of its total consumption of cereals come from rich countries, where less than four percent of the population worked in agriculture, and were presently covering the needs of the entire urban population of SubSaharan Africa. It is therefore not surprising that value addition in Africa was yet to be influenced by trade liberalization positively. FAO (2003)'s assertion that trade liberalization effects on agricultural export or value addition was weak, was evidenced by the findings of this work. It would be recalled that FAO noted that while there was fairly convincing crosscountry evidence that exports are associated with growth, the evidence that liberalization increases growth is much weaker in SSA.

\section{CONCLUSION}

It has been established in this research that electricity supply is an infrastructure that significantly influences level of agricultural value addition in Africa in both short- and long run. African policy makers and institutions involved in development should therefore focus more on sustainable implementation of electric power reform programmes that will provide a more steady power supply and lower energy prices in their countries in order to boost agricultural value addition and economic growth arising from improved productivity of farm households and agribusinesses. It is evidenced from this present study that technology plays a significant role in the short term and long run determination of value addition in African agriculture. It is however worrisome that in the short run technology was impacting negatively on agricultural value chain growth in Africa, suggesting possible adoption of inappropriate or up to date technology in agricultural value addition. Given this role of technology on agricultural value addition, efforts must be made by African policy makers to invest in modern farm machineries, technologies as well as capacity building in the development and use of appropriate technologies that will enhance increased value addition in African agriculture. It is also recommended that CAADP, African regional trade organizations and government 
authorities should renew their emphasis on substantially producing the required raw materials for agro-allied and agro-based manufacturing/ processing companies to help build African value addition in agriculture's capacity.

\section{Acknowledgment}

The researchers are grateful to Trade Policy Training Centre for Africa (TRAPCA) for providing the travel grant used in disseminating this research findings during the annual Trade Forum in Arusha, Tanzania, in 2014.

\section{REFERENCES}

Atif, R.M., Jadoon, A., Zaman, K., Ismail, A. and Seemab, R, (2010). "Trade Liberalisation, Financial Development and Economic Growth: Evidence from Pakistan (1980-2009)". Journal of International Academic Research 10(2): 30-7.

Bardsen, G. (1989). "Estimation of Long-Run Coefficients in Error-Correction Models". Bulletin 51: $345-50$

Bharati P. \& Chaudhury, A. 2012. Technology assimilation across the value chain: an empirical study of small and medium-sized enterprises. Information Resources Management Journal, 25(1): 38-60

De Vylda S. (2007). The Least Developed Countries and World Trade - Second Edition, SIdA Studies No. 19. Swedish International Development Cooperation Agency: Stockholm, Sweden.

Escaith H \& Tamenu, B. (2013). Least-developed countries' trade during the "super-cycle" and the great trade collapse: patterns and stylized facts. World Trade Organization, WTO Economic Research and Statistics Division, Staff Working Paper Staff Working Paper ERSD-2013-12

Federal Government of Nigeria, FGN (2009). Nigeria Vision 20: 2020 Economic Transformation Blueprint. National Planning Commission, Abuja..

Food and Agricultural organization, FAO, (2003). Trade reforms and food security: Conceptualizing the linkages. Food and Agricultural Organization of the United Nations; Rome. http://www.fao.org/docrep/005/y4671e/y4671e00.htm\#Contents

Greene W.H. (2008) Econometric Analysis (6th edition) New York University Press 
Gujarati, D. and Sangeetha (2007). Basic Econometrics: Cointegration and Error Correction Model. New Delhi: Tata McGraw-Hill Publishing Company Limited

Halilu M. (2014). ICT - all that is between Rwanda and value-added agriculture. A speech at the International Conference on ICT for Agriculture (ICT4Ag) by the director of CTA (Technical Centre for Agriculture and Rural Cooperation), at the Conference being held in Kigali, Rwanda, March.

Ladele, A.A, Oyelami, B.O. and Balogun, O.T. (2015) "Extents Of Sharp Practices In Credit Allocation And Utilization Among Staff And Beneficiaries Of The Bank Of Agriculture In Oyo State" Agrosearch 15 (2): 31-45 http://dx.doi.org/10.4314/agrosh.v15i2.4

Miller C. \& Jones L. (2010). Agricultural Value Chain Finance Tools and Lessons Food and Agricultural Organization, FAO: Rome. Available at http://www.fao.org/docrep/017/i0846e/i0846e.pdf

Kalaba M. \& Kirsten J. n.d. Determinants of trade patterns and comparative advantage of processed agricultural products in SADC. Available at http://web.up.ac.za/sitefiles/file/48/2052/2012\%20Working\%20Papers/IntraSADC $\% 20$ Trade $\% 20$ of\%20processed $\% 20$ agric\%20products 4 Mar13.pdf

Ngore P. M. 2010. Evaluation of factors influencing value addition by butchery agribusinesses in Igembe North District, Kenya. A thesis submitted to the Graduate School in partial fulfillment of the requirements for the award of Master of Science Degree in Agricultural and Applied Economics, Egerton University. Accessed on 11/03/2014 from http://ageconsearch.umn.edu/bitstream/134498/2/Thesis\%20\%20Muthee.pdf

Olatunji, G.B., Omotesho, O.A., Ayinde, O.E and Adewumi, M.O. (2012) 'Empirical Analysis of Agricultural Production and Inflation Rate in Nigeria (1970-2006)' Agrosearch 12 (1): 21 - 30 http://dx.doi.org/10.4314/agrosh.v.12i1.2

Oluwasola, O. and Alimi T. (2007) "Financial Intermediation In Agriculture In Nigeria: Emerging Role Of Non-Governmental Organizations (NGOs)" Agrosearch 9 (1\&2): 43 - 51

Pesaran, M.H., Shin, Y. and Smith, R. J.,(2001) "Bounds testing approaches to the analysis of level relationships". Journal of Applied Econometrics, 16: 289-326. 
Reid J. F. 2011. The impact of mechanization on agriculture. The Bridge, 41(3): 22-29/ Accessed on 14/03/2014 from http://www.nae.edu/File.aspx?id=52553

Trade Policy Centre for Africa, TRAPCA 2014.Trade reform, trade patterns and global value chains. Trade Policy Research Forum Call for Papers, Arusha, Tanzania. Retrieved on 20/02/2014 from http://trapca.org/\#

United Nations Industrial Development Organization UNIDO (2006) Industrial development, trade and poverty reduction through South-South co-operation. Retrieved on 22/02/2014 from http://www.unido.org/fileadmin/user_media_upgrade/What_we_do/Topics/SouthSouth_Cooperation/industrial_development_south_south_cooperation.pdf

UNIDO, CBN, BOI 2010. Unleashing Agricultural development potentials in Nigeria through Value Chain financing. Working Paper, November, 2010.United Nations Industrial Development Organization,: Vienna, Austria.

Venkatachalam L. 2003. Infrastructure and agricultural development in Karnataka State.Agricultural Development \& Rural Transformation (ADRT) Unit Institute for Social and Economic Change, Nagarbhavi, Bangalore. Availabe at http://www.isec.ac.in/AGRL\%20DEVELOPMENT.pdf

World Bank 2007. Using Value Chain Approaches in Agribusiness and Agriculture in SubSaharan Africa: A Methodological Guide. Tools That Make Value Chains Work: Discussion and Cases', prepared for the World Bank by J.E. Austin Associates, Inc. Working Paper 063

World Bank 2010._Building Competitiveness in Africa's Agriculture.World Bank: Washington D. C. Available at http://www.worldbank.org/pdt

World Bank (2013). "Africa: take a look at Africa." Retrieved on 21 st March, 2017 from www.worldbank.org The World Bank: Washington D. C.

World Bank (2014). Agriculture and rural development. Accessed on 20/02/2014 from http://web.worldbank.org/WBSITE/EXTERNAL/TOPICS/EXTARD/0, contentMDK:2045 1181 menuPK:336688 pagePK:148956 piPK:216618 theSitePK:336682,00.html 